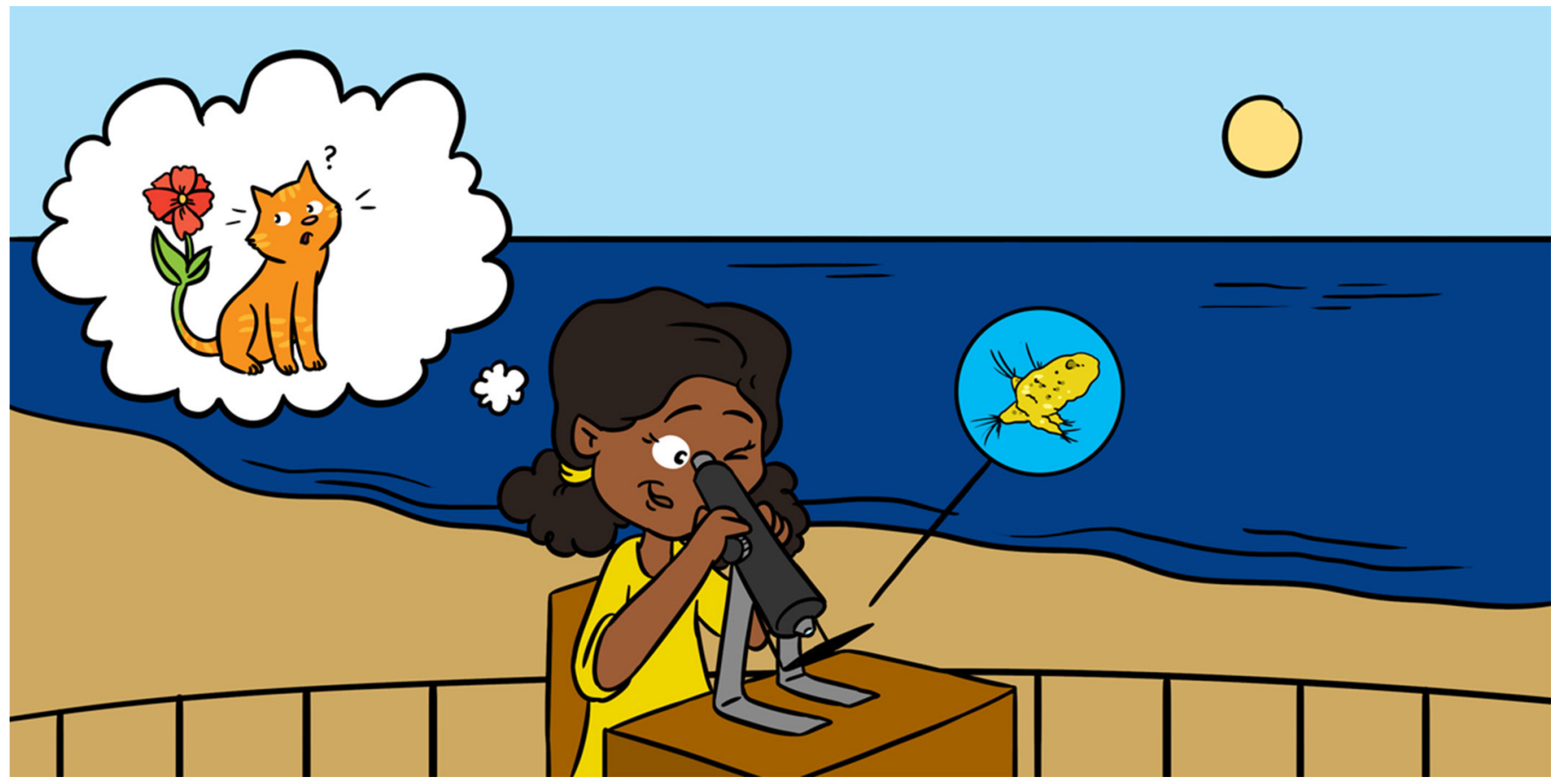

\title{
PLANTS ARE NOT ANIMALS AND ANIMALS ARE NOT PLANTS, RIGHT? WRONG! TINY CREATURES IN THE OCEAN CAN BE BOTH AT ONCE!
}

\section{Patricia M. Glibert ${ }^{1^{*}}$, Aditee Mitra ${ }^{2}$, Kevin J. Flynn ${ }^{2}$, Per Juel Hansen ${ }^{3}$, Hae Jin Jeong ${ }^{4}$ and Diane Stoecker}

${ }^{1}$ Horn Point Laboratory, University of Maryland Center for Environmental Science, Cambridge, MD, United States

2 Department of Biosciences, Swansea University, Swansea, United Kingdom

${ }_{3}^{3}$ Marine Biological Section, University of Copenhagen, Helsingør, Denmark

${ }^{4}$ School of Earth and Environmental Science, College of Natural Sciences, Seoul National University, Seoul, South Korea

YOUNG REVIEWERS:

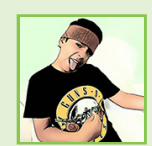

FROYLAN

AGE: 11

NICOLAS

AGE: 8
On land, plants make their own food by photosynthesis and animals live by eating. However, in the microscopic world in the oceans, it is not that simple. Many microscopic so-called plants (phytoplankton) can also eat like animals and many microscopic so-called animals (microzooplankton) can also photosynthesize like plants! More amazingly, some of these microzooplankton eat tiny phytoplankton and continue to live off photosynthesis from those ingested phytoplankton. These organisms acting like both plants and animals are called mixotrophs because they mix (combine) different ways of getting nutrition. These fascinating creatures are not rare freaks of nature, but are very common. Some mixotrophs are good food for fish, while others make poisons that can get into our seafood and even 


\section{PHOTOSYNTHESIS}

The process by which green plants and plant-like algae use sunlight, together with carbon dioxide and water, to make their own food.

\section{PLANKTON/}

PHYTOPLANKTON/ MICROZOOPLANKTON

Plankton are drifting or floating organisms in the sea or in freshwater. Most are microscopic When plant-like, they are called

phytoplankton, and when animal-like, they are called zooplankton. Small-sized zooplankton are termed microzooplankton.

Figure 1

(A) Cartoons of a hungry plant photosynthesizing (left) and eating (right).

(B) The Venus flytrap plant both photosynthesizes and eats insects. Cartoon by H. J. Jeong, photos from Shutterstock. kill fish. Some are increasing in coastal waters due to pollution. We are learning just how important mixotrophs are to ocean ecosystems.

One of the most basic "laws" of science is that plants are plants and animals are animals. Right? Of course! Plants are green. They live using sunlight, carbon dioxide, and nutrients, making their own food through the process of photosynthesis. In contrast, animals live by eating other organisms (plants, animals, bacteria, or even bits and pieces of dead organisms). Is this "law" of science correct? Not always! Going against this "law" are oceans full of microscopic organisms that can be both plant-like and animal-like at the same time! They photosynthesize and eat.

Have you ever heard of a plant that can eat an animal? There are a few land plants that eat insects. The most commonly known example is the Venus flytrap, which captures insects on its special leaves and then digests them (Figure 1A). Such land plants are considered a bit of a freak of nature. In the ocean, however, these freaks are not freaks at all; they are actually very common. You can find many of these kinds of organisms if you look under the microscope and explore the microbial plankton, the tiny organisms that live in the water world. Not only are there plants that eat, there are animals that photosynthesize! These fascinating, mixed ways of getting and making food are called mixotrophy and the organisms that perform mixotrophy are called mixotrophs (meaning mixed nutrition). A non-science term for these organisms could be "plantimals," since they can be part-plant, part-animal (Figure 1).
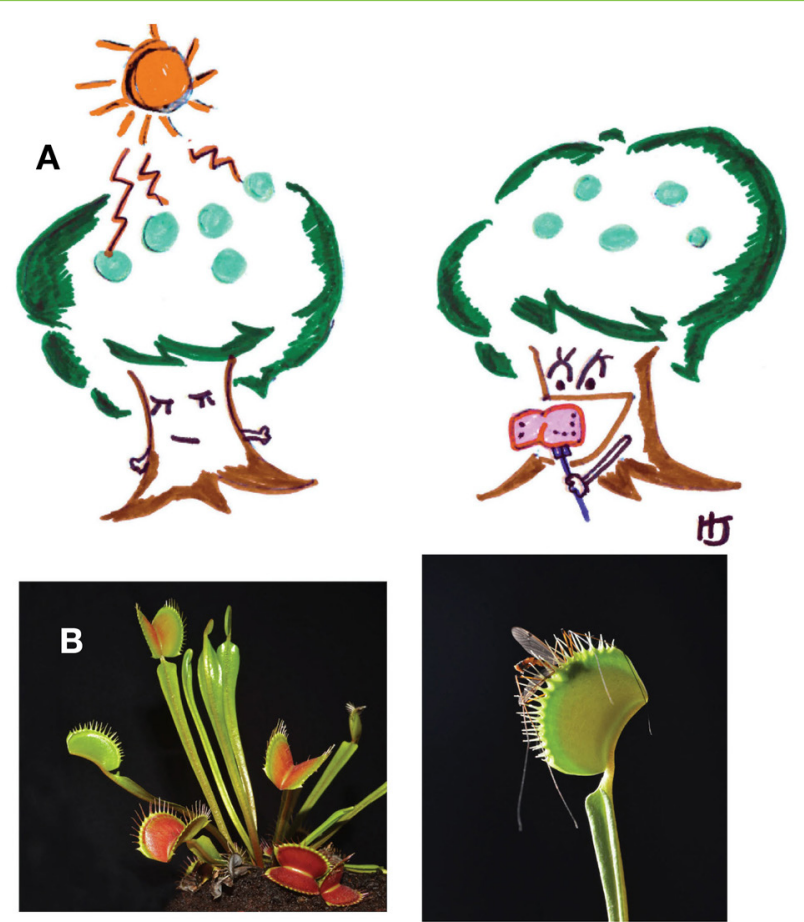

Figure 1 
MIXOTROPHY/

\section{MIXOTROPH}

Mixotrophy is the process of combining photosynthesis (like a plant) and feeding (like an animal) in one organism. A mixotroph is an organism that combines its nutrition in this way.

Figure 2

(A) Cartoons of microscopic phytoplankton called mixotrophs. They live off of sunlight and photosynthesis (upper panel) but can also have a meal of another small cell (lower panel). (B) The plant-like (phytoplankton-like) mixotroph Karlodinium captures (top two panels), then ingests (bottom panel) a small cell. Cartoon by H. J. Jeong and image from Stoecker et al. [2] (reproduced with permission of SpringerVerlag).

\section{PLANKTONIC PLANTS THAT ARE ALSO ANIMALS}

Phytoplankton are microscopic plant-like organisms that live in the water. Their name tells us that they live on light (phyto) and drift with the water (plankton). Every drop of water normally contains hundreds of thousands of these tiny, single-celled organisms. Phytoplankton are natural and important; they produce $50 \%$ of the oxygen in the air we breathe, and they are also food for fish and other animals in the ocean. There are many hundreds of different types of phytoplankton. For decades, most scientists have thought that phytoplankton lived only by photosynthesis. It turns out that many of these phytoplankton also eat the way animals do [1]. Some eat other phytoplankton, some eat bacteria, and some eat tiny animals (Figure 2). Some of these mixotroph phytoplankton eat only reluctantly or rarely. Some are aggressive and can stuff themselves full of food! These mixotrophs grow much faster when they can eat and photosynthesize at the same time, compared with when they grow by photosynthesis alone.

The ways the mixotrophic phytoplankton eat can be pretty gruesome. Some gobble up entire organisms, while some harpoon their food and suck out the innards using a self-made straw. Some can make their meal explode, leaving a nutritious soup that they can soak up. Some can even eat other organisms that are much bigger than themselves.

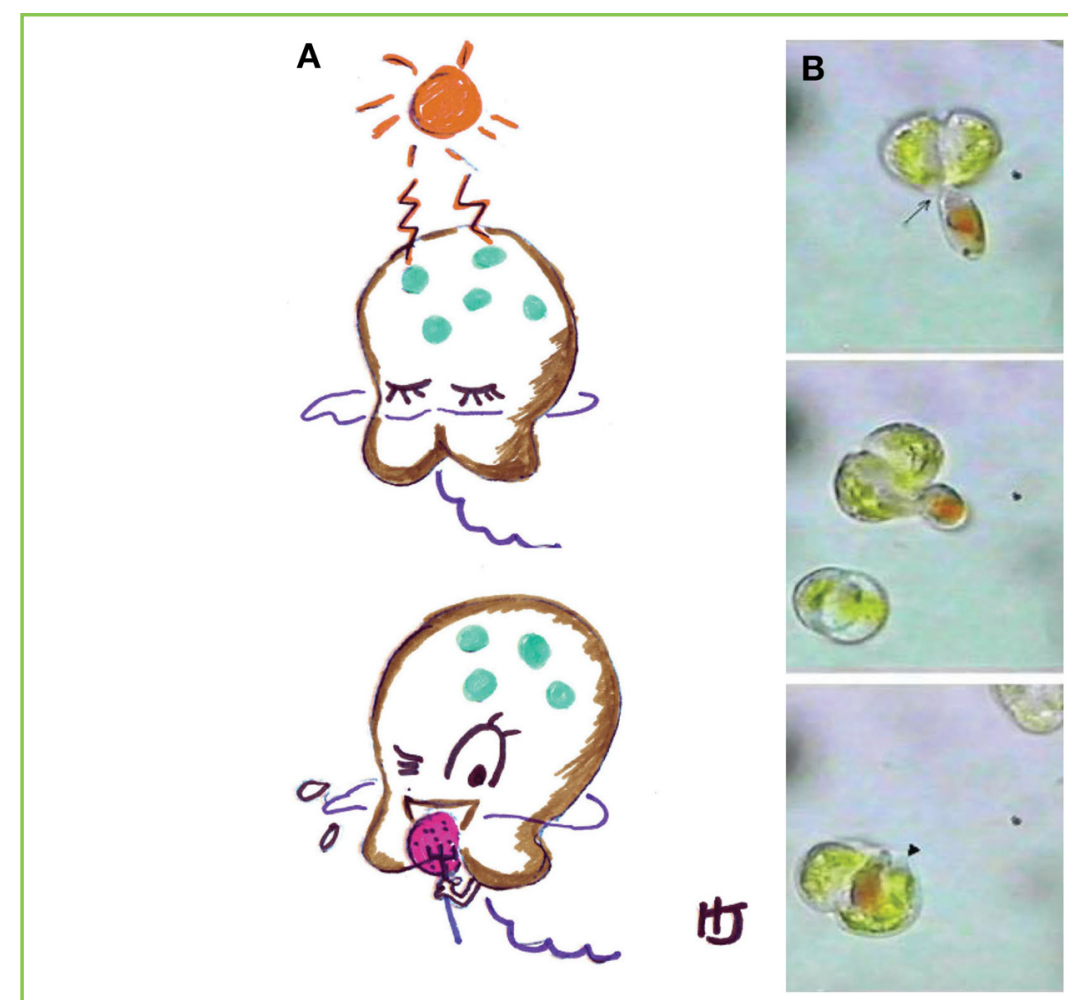




\section{CHLOROPLAST}

Photosynthesizing apparatus in plants and marine phytoplankton.

Figure 3

(A) Cartoons of a hungry

microzooplankton (left panel), eating small phytoplankton (middle panel), then capturing sunlight for photosynthesis, using the phytoplankton chloroplasts now inside its body (right panel).

(B) The mixotroph Dinophysis beginning to get its meal from Mesodinium. Note the small red circles inside the Mesodinium-these are the algae the Mesodinium ate! The arrow points to the small straw or feeding tube it uses to feed on Mesodinium. Cartoon by $\mathrm{H}$. J. Jeong and image from Park et al. [3] (reproduced under Creative commons license).
Some mixotrophic phytoplankton use poisons to kill what they want to eat. Interestingly, some can make these poisons only when they photosynthesize AND eat at the same time. An example is an organism called Karlodinium. Karlodinium eats other small algae aggressively, but it seems to only eat during daylight. Why does it not also eat at night? It turns out that Karlodinium makes the poisonous compound that it releases to kill its food during daytime, when it is also photosynthesizing.

\section{PLANKTONIC ANIMALS THAT ARE ALSO PLANTS}

Along with phytoplankton, there are other, tiny animal-like organisms in the ocean that are called microzooplankton, because they are small (micro-), animal (zoo-)-like plankton. Microzooplankton eat lots of different things, but when they eat tiny phytoplankton, they can become part-time plants. How can they do this? One type of microzooplankton eats phytoplankton, but they do not digest the photosynthesizing machinery (the chloroplasts; Figure 3). They keep the stolen chloroplasts and use these to photosynthesize! Can you imagine the broccoli
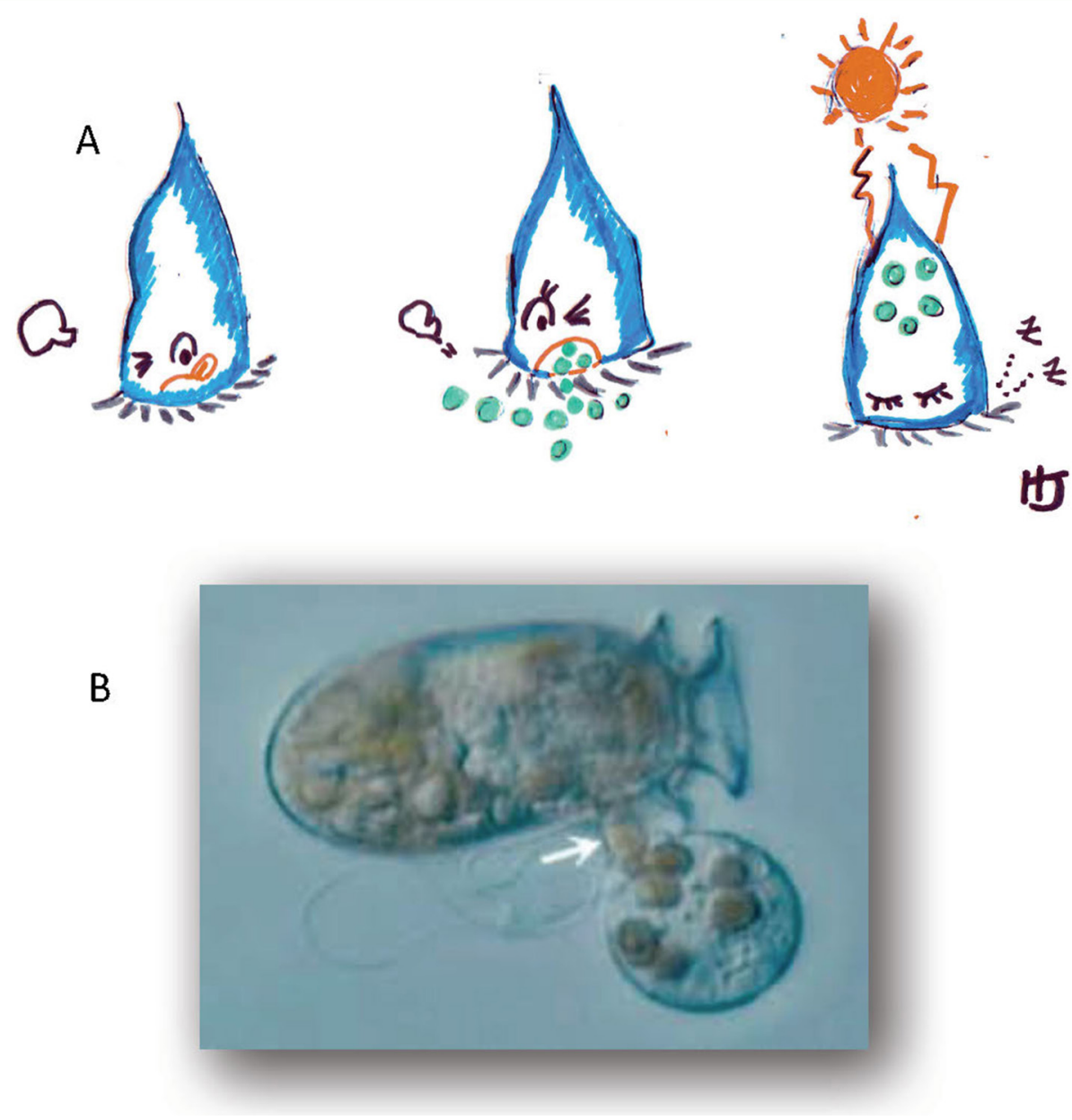

Figure 3 
you eat continuing to photosynthesize in your stomach after you ate it? Other "animal" mixotrophs eat lots of phytoplankton but do not digest them at all-they keep the intact phytoplankton within their bodies and drift in the oceans like microscopic greenhouses; they live off the photosynthesis from the still-growing phytoplankton they ate.

Some mixotrophic microzooplankton are picky eaters, and become plant-like only by eating their favorite foods. One type of these picky mixotrophs is a species called Dinophysis, which is found in oceans all over the world. Dinophysis wants chloroplasts from one specific type of microscopic phytoplankton but cannot eat those phytoplankton directly. So Dinophysis eats another mixotroph named Mesodinium that eats the specific phytoplankton with those chloroplasts. The Dinophysis then pokes a hole into the Mesodinium and sucks all their guts out to finally get the chloroplasts it wants.

Talk about gruesome, picky eaters! It is real microbial warfare in the oceans!

\section{WHERE ARE MIXOTROPHIC PLANKTON FOUND IN THE OCEANS?}

All our oceans are home to mixotrophic plankton, but different types live in different parts of the ocean or at different times of year. Some types, such as the Karlodinium, are mainly found along coastal areas, while other types are more common in the open waters of the oceans. Other types of mixotrophic plankton are associated with polar waters or tropical waters. Some are more common during certain seasonsespecially summer.

EUTROPHICATION

The process of enriching a body of water with nutrients. Eutrophication can result in harmful algal blooms or other negative effects on the ecosystem.
Many mixotrophs grow very well in waters that have become eutrophic (enriched with too many nutrients or fertilizers) from all of our human wastes [4]. When we apply fertilizers to lawns or farm land, not all of that fertilizer is used by grass or by crops. Some of the fertilizers are washed out to sea after it rains. These fertilizers then feed the phytoplankton in the ocean water, which then grow, becoming food for other plankton, including the mixotrophs. With more food, mixotrophs can grow more and more. When phytoplankton, including those that are mixotrophs, grow in large numbers it is called a bloom.

\section{WHY SHOULD WE BE INTERESTED IN MIXOTROPHS?}

Mixotrophy is now considered so important in the plankton communities that it has been proclaimed as one of the recent revolutions/dis- 
coveries in science that could change everything (Scientific American Vol. 27, No. 3, July 2018)! Mixotrophy changes the way we think about all aspects of life under the water [1]. Plankton life does not fall neatly into plant and animal categories, as does life on land. In the world of plankton, there is still much that we do not know or understand. As scientists, it is really cool to try to figure out how mixotrophs work! There are endless numbers of questions that we have and important topics that can be explored with these amazing little creatures [5].

Scientists are also very interested in mixotrophic plankton because they ultimately sustain all the other organisms in the ocean, from oysters and crabs to fish. With climate change, we also want to know how organisms in the oceans, including mixotrophs, are changing and how that may change the populations of fish that humans use for food [1].

Many of the plant-like mixotrophs can harm other types of organisms, including whales, dolphins, or turtles. Figuring out how mixotrophs affect these larger organisms is important if we want to protect those important creatures. The day-time eater Karlodinium can release some of its poisons into the water, destroying the gills of fish, which kills the fish almost immediately. Karlodinium then eat bits of fish for their dinner. Others, such as Karenia brevis off the coast of Florida, produce a poisonous compound that may not only kill fish, but is strong enough to kill even huge manatees! In the summer of 2018, Karenia brevis blooms resulted in large fish kills off the Florida coast; many sick and dead animals washed ashore, including over 100 manatees and 300 turtles. This was a terrible loss of marine life and also made the beaches slimy and smelly.

Scientists are especially interested in mixotrophs that make poisonous compounds that can make people sick. If we eat mussels that fed on Dinophysis, the picky-eater-mixotroph mentioned above, we can get diarrhetic shellfish poisoning; this means that people get upset stomachs and have diarrhea. The toxic compound made by Karenia brevis can get carried in sea spray and makes us cough if we breathe that air at the beach. The types of toxic compounds made by different mixotrophs are very diverse and there is much we still do not know about the chemistry of these compounds. We are very interested in understanding what we can do to stop these tiny, toxic organisms from growing out of control and how we can keep people from getting sick.

These amazing mixotrophs, with their fascinating diversity, are certainly shaping our oceans and the food we get from it. It may seem to be a mixed-up world of microbes in our oceans, but they are major players on our planet. Therefore, they are worthy of our attention. 
Scientists, fishermen, seafood lovers, beach goers, environmentalists, and all citizens of the planet should care about what lives and grows in our oceans!

\section{For more information on mixotrophs}

www.mixotroph.org

\section{ACKNOWLEDGMENTS}

The authors received support from the following agencies for their work on mixotrophy: the US National Oceanic and Atmospheric Administration National Centers for Coastal Ocean Science Competitive Research program under award No. NA17NOS4780180 (PG), the European Commission's Horizon 2020 Research and Innovation Programme under the Marie Skłodowska-Curie MixITiN grant agreement No 766327 (AM, KF, and PH), a grant (no. 4181-00484) from the Danish Research Council for Independent Research (PH), and the Useful Dinoflagellate Program of Korea Institute of Marine Science and Technology Promotion (HJ). The authors thank Rohan Mitra-Flynn for helpful comments on this paper. This is contribution number 5535 from the University of Maryland Center for Environmental Science and ECO933 from the NOAA ECOHAB Program.

\section{REFERENCES}

1. Mitra, A. 2016. Uncovered: The Mysterious Killer Triffids That Dominate Life in Our Oceans. The Conversation.

2. Stoecker, D. K., Tillmann, U., and Granéli, E. 2006. "Phagotrophy in harmful algae," in Ecology of Harmful Algae, eds E. Granéli, and J. Turner (Springer: The Netherlands), 177-87.

3. Park M. G., Kim, S., Kim, H. S., Myung, G., Kang, Y. G., Yih, W. 2006. First successful culture of the marine dinoflagellate Dinophysis acuminata. Aquat. Microb. Ecol. 45:101-6. doi: 10.3354/ame045101

4. Burkholder, J. M., Glibert, P. M., and Skelton, H. M. 2008. Mixotrophy, a major mode of nutrition for harmful algal species in eutrophic waters. Harmful Algae 8:77-93. doi: 10.1016/j.hal.2008.08.010

5. Flynn, K. J., Stoecker, D. K., Mitra, A., Raven, J. A., Glibert, P. M. Hansen, P. J., et al. 2013. Misuse of the phytoplankton-zooplankton dichotomy: the need to assign organisms as mixotrophs within plankton functional types. J. Plankton Res. 35:3-11. doi: 10.1093/plankt/fbs062

SUBMITTED: 26 November 2018; ACCEPTED: 04 March 2019;

PUBLISHED ONLINE: 27 March 2019. 
EDITED BY: Angelica Cibrian-Jaramillo, Centro de Investigación y de Estudios Avanzados (CINVESTAV), Mexico

CITATION: Glibert PM, Mitra A, Flynn KJ, Hansen PJ, Jeong HJ and Stoecker D (2019) Plants Are Not Animals and Animals Are Not Plants, Right? Wrong! Tiny Creatures in the Ocean Can be Both at Once! Front. Young Minds 7:48. doi: 10.3389/ frym.2019.00048

CONFLICT OF INTEREST STATEMENT: The authors declare that the research was conducted in the absence of any commercial or financial relationships that could be construed as a potential conflict of interest.

COPYRIGHT @ 2019 Glibert, Mitra, Flynn, Hansen, Jeong and Stoecker. This is an open-access article distributed under the terms of the Creative Commons Attribution License (CC BY). The use, distribution or reproduction in other forums is permitted, provided the original author(s) and the copyright owner(s) are credited and that the original publication in this journal is cited, in accordance with accepted academic practice. No use, distribution or reproduction is permitted which does not comply with these terms.
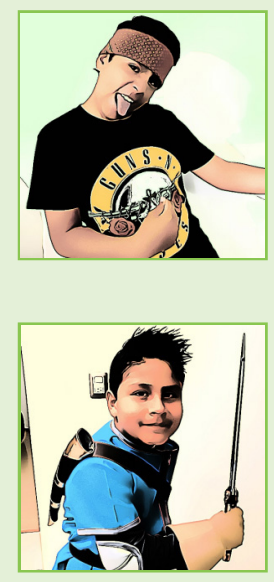

\section{YOUNG REVIEWERS}

\section{FROYLAN, AGE: 11}

My favorite hobby is drawing, I can draw almost any character from movies or video games, I also like to create new characters and write new stories. I practice American Football since I was 7 years old, this year I will play my fifth season, and my position is Center.

\section{NICOLAS, AGE: 8}

My favorite hobby is the computer I like to research everything; I also like to play Minecraft. I love creating new worlds, I have dozens of them. I would love to travel around the world and meet amazing people and places. I practice American Football since I was 5 years old, this year I will play my fifth season, and my position in the offense is Center and in defense is Nose Tackle.

\section{AUTHORS}

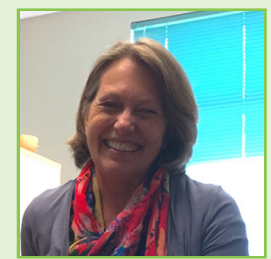

\section{PATRICIA M. GLIBERT}

I study algae because I hope what we are doing makes a difference in the world. These are certainly interesting times to be an ecologist studying water quality. Phytoplankton blooms are increasingly everywhere, and nutrient pollution and eutrophication are increasing. It used to be difficult to explain what I studied to my non-scientists friends and relatives; now, they read the headlines of water quality issues and algal blooms frequently. I study algae all around the world, from Chesapeake Bay to Florida, and from Europe to China! *glibert@umces.edu 

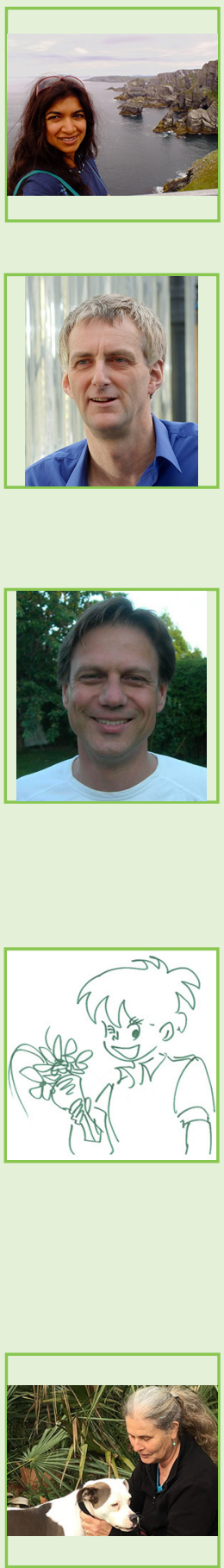

\section{ADITEE MITRA}

I have always thrived on challenges-doing something new, finding something different-that is why I love working on mixotrophs! Our research findings revealed that the mixoplankton actually rule our oceans. Mixotrophs are not only cool, but fun to study!

\section{KEVIN J. FLYNN}

When I was studying for my Ph.D., I wrote computer games for fun. Now, instead of aliens battling it out against each other, I use that skill to write computer simulations of different plankton "fighting" for life! I found out that you learn quickly when having fun and building and playing with simulations of plankton is a great way to find out how nature works!

\section{PER JUEL HANSEN}

I am an experimental biologist that study how plankton organisms interact with each other and how they interact with the environment. I am particularly interested in how harmful algal blooms develop and how bloom-forming toxic algae use their toxins to kill and eat other organisms to get rid of competitors and enemies. I work in the Arctic waters of Greenland, temperate waters in Northern Europe and in tropical waters in Asia.

\section{HAE JIN JEONG}

I am very interested in solving harmful algal blooms (HABs), one of the biggest problems at sea. I have developed several methods of eliminating HAB species using mass-cultured predators and some effective chemicals. However, I realized that some HAB species have genomes up to 90 times larger than mine, and I determined that I must become their friend and understand their minds. Now I try to focus on converting "harmful" algae to "useful" algae for humans. For fun I like to draw cartoons and make jokes!

\section{DIANE STOECKER}

I study plankton because they are beautiful, live in the sea, and because there are many species that we know little about. I like to go to sea to do research and to work with cultures in the laboratory. Making discoveries about tiny plankton has been fun and has allowed me to work with scientists in many countries. 